\title{
Local Political Arrangements: Education in harmony with the local development
}

\author{
Marli Alves Flores Melo \\ floresmelo@gmail.com \\ Universidade Católica de Brasilia, Brazil
}

\begin{abstract}
This paper addresses education, particularly professional, scientific and technological education, in the context of local development, from the prism of productive local arrangements - PLAS. It highlights the effect of globalization on society's transformations, the restructuring of the sectorial, institutional and organizational dynamics related to educational aspects, the territorial features of the said arrangements, and the actors that are part of them. We understand that this is a priority in the social construction and an incentive to the scientific education professional development, with regard to the ethical-political nature of individuals. We point out the need to foster interaction amongst educational institutions in order to mobilize territorial resources, aiming at local development. We conclude with a few pertinent discussions about the value of education, both in its integral feature and in its adherence to parallel harmonies.
\end{abstract}

\section{Introduction}

Historically, in Brazil, some of the directions proposed by the Government's Educational Policies have been registered including the maintenance of the highly regarded concept of professional, scientific and technological education, whose reference was the performance of former technical courses' students that managed to get good jobs and also succeeded in entering university courses at famous Federal Universities.

Currently, this trend is becoming stronger due to the growing awareness of the advantages for the country from the perspective of growth and the establishment of socialpolitical development. As a consequence, new goals have been established for professional scientific and technological teaching with the following objectives: ${ }^{1}$ to expand the offer of technical courses for secondary school, to bring these offers to the hinterlands and to make access to them democratic, to foster the initial and continued in class and distance learning or qualification, to offer technological undergraduate courses to develop the Technical Teaching skills of teachers in the Professional Education Federal Network, as well as Postgraduation courses (Lato Sensu) and Masters' and Doctorate courses (Sctricto Sensu).

We can observe that, on the basis of the integrated and professional secondary school expansion goals, the school community retrieves the meaning of professional education for the job, particularly in the form of reorganizing the political-pedagogical projects and the relations that are internally and externally established amongst the subjects involved.

Along this line of thought, some scholars and researchers in the area of Education have questioned the educational dualism: What is the concept that we have of education and of professional, scientific and technological education?

This question places secondary school technological and professional education as something distinct from basic education, which can be justified by the contradictory contrast

${ }^{1}$ See the website-http://pronatec.mec.gov.br/institutional/objectives-and-initiatives/2012. 
between the continuity and discontinuity of governmental and non-governmental initiatives for the constitution and continuity of processes that will maximize the whole knowledge of the Brazilian student, not only the intention of qualifying labor for the job market. Within this context, Gramsci (1989) argues in favor of education as a process of the human being's whole development and as a determinant to raise cultural levels in reference to a process of theoretical construction and practice of a conception of the world in its political, economic and social dimensions. In addition, he states that the educational process goes through the principle of labor by dealing with the sociability and forms of material and intellectual production of life, and articulately encompasses science, techniques and technology, ethics, politics and economics.

On the other hand, Saviani (1989) argues that Education, in general, should be synchronized with technology to give the students opportunities to dominate the scientific principles and foundations, as long as the technique of production is differentiated and will foster multilateral development. Essentially, those approaches are brought forth in the discussions about the universalization of quality basic elementary and secondary education, followed by higher education. This suggests the overcoming of the education consensus geared towards a work field or only for the training in mere professions, but which must also be projected on the idea of the human being's whole development divided between the social construction and the stimulus to professional development, as well as the guaranteeing of the rights and the carrying out of actions to better think, direct or plan an understanding of the world as a dignified and inserted citizen in his political society (Ciavatta, Frigotto \& Ramos, 2005).

Another viable option is for us to consider the articulation of technical and professional courses to be offered at the technical, professional education schools (TPE) and at the integrated secondary schools (ISS), in accordance with the local productive arrangements (LPAs) (productive avocations), which can become development and sustainability tools at the local sphere for the global realm. The aforementioned arrangements, according to Cassiolato \& Lastres (2008a) and Cassiolato, Lastres \& Stallivieri (2008b) have increasingly been used by both research groups concerned with understanding the development processes characteristic of the current capitalism stage, as well as by several public and private policy agencies in charge of fostering the development of the production of goods and services.

Based on such aspects, this paper addresses education, specially the professional, scientific and technological education approaches, as an agent of local development, just like the effects of globalization on the local, productive arrangements, the actors that are part of those arrangements, in harmony with the "human territory", in the sense of destiny, construction of the future (Santos \& Silveira, 2002. p. 19).

The text is divided into three parts. The first one places education in the globalized context of local development. The second one presents the history of the local, productive arrangements and their agents, with an emphasis on the discussions of the themes approached in meetings and seminars. The last part analyzes the possibilities of professional, scientific and technological education with regard to local development.

\section{Professional, scientific and technological education, globalization and development}

Education is acknowledged as a universally accepted condition for social development. With regard to that, Abdi (2012) and Abdi \& Duo (2008) express opinions in the sense that it is possible to foster development by means of education: "the overcoming of social 
inequalities, the achievement of actual and effective democracy, justice, full universal citizenship, political, economic and technological sovereignty, and culture".

Abdi \& Duo (2008) say that the relationship between education and social development is positive to give ample meaning to local development. They state that, in itself, education is always present in the lives of societies providing people with subsistence means, welfare, and opportunities in relation to the world. The authors emphasize the social term that encompasses the sets of ways of life - economic, political, educational, technological, emotional and others, that directly or indirectly affect people's lives.

Parallel to that, we understand that professional, scientific and technological education can be an essential link to foster the development pictured by local "progress". Within this perspective, the formalization of a society project is necessary, including the spaces of the human territories occupied by the actors that utilize them and that will have an environment propitious to the discussion of issues related to social inequalities and social justice, among others.

The territory referred to is interconnected with globalized capitalism for the obligatory high level of competitiveness, with the objective of reaching productivity that will depend on the conditions offered locally. This occurs due to the speed with which information arrives and transforms places, just as it brings people to other spaces and, as a result, provokes their distancing from productive processes.

For that matter, Santos \& Silveira (2002) highlight the fact that technological progress increasingly submits to the global logic, electing territorial points of interest in its requirements to improve functionality, appropriate local and regional equipment and to improve its connections by means of modern informational materials that tend to reconcentration. In that sense, Shultz (2012, p. 37) explains:

In our globalized world, full of movement and communication between geographical, political and social barriers, it is important to understand the processes of development of global policies and the forms by which such policies cause an impact on the connection systems and sites. The connection between the knowledge of global policy development and the creation and exchange of citizenship platforms and human dignity can provide an engagement on several scales, with cultural values and experiences in the community, as a way to reimagine education possibilities within a globalized context. For that to happen, we need to demand educational spaces that will meet the needs of democracy and social justice for all the members of society.

We know that globalization is imposed onto the world's society in a manner similar to colonialism, but by means of modern methods like the benefit of a free market in defense of the end of national barriers, orientation of economic directions, interference with the rulers' decision-power capability, standardization of information that interacts with the capitalist system's interests both in the economic societies and in the more advanced technological ones, global projection in opposition to the West's, whose results will produce effective effects in the education policies. (Abdi, 2012, Olssen, Codd \& O`Neill, 2004, and Shultz, 2012).

Specifically, about the world's society, Santos (1999) argues that it would be an abstract notion that acquires materialness on the global scale so that we may understand the phenomenon of globalization. The evidence of the maximized globalization context remains, hence, in place and alters the place's value, to establish a causal relation and benefit the hegemonic actors, i.e. those with action capability or systemic relevance, whose unilateral 
actions can alter the system's balance, one of the other's, in his territory, as a result of the changes in the functionality of resources and of identity (Sousa Santos, 2006).

For Sousa Santos (2006), hegemonic globalization portrays the first globalization production mode, in combination with the globalized localism, justified when a concept becomes global by localized globalism.

We can add to that the understanding of the term "glocalization" presented by Abdi (2012, p. 44) in the following conceptualization:

(...) a practical idea that evidences globalization not as a unidirectional phenomenon, and that in the old life spaces must have the meaning of expanding the locale to other localities, in the regional, national and continental realities Likewise: it refers to the complex realities of global forces that affect the local contexts and the locale actively interacting with each other, which directly contributes to change the qualitative effects and the globalization results (...).

\section{The history of the local productive arrangements and actors}

We find it important to report, by timeline, that in the 1990's, discussions were promoted by the Ministry of Sciences and Technology, considering the difficulty of characterizing and analyzing the countless experiences of geographical and sectorial agglomerations of enterprises, support institutions, universities, research centers, class associations, governmental agencies, and financial institutions (Costa, 2010). As of this landmark, the term local productive arrangement (LPA) originated.

Currently, in search of a universally accepted concept, we have found in the specialized publications a diversity of terminologies used in reference to those arrangements, in whose conceptualizations we detected common characteristics, as Coriolano (2009, pp. 2829) points out with regard to:

Clusters: meaning the grouping, collection, gathering, bunch. It is an anglo-saxon term that synthetizes concept and local development strategies. It deals with a large set of localized enterprises, in general, small and medium-size, operating in a regime of intense cooperation, each of the firms carrying out a stage in the production process.

Local productive arrangement: a term derived from the previous system, meaning an approach to the concept of the Brazilian reality, once the Brazilian agglomerations are still in a stage of interdependence, between the enterprises and these and the supporting institutions. The consolidation of the arrangement depends on the four essential elements: territory, social capital, productive organization, political-institutional articulation and market strategy.

It can be observed that, specifically, the arrangement mentioned above was mapped in more than thirty governmental entities, under the coordination of the Ministry of Development, Industry and Foreign Trade (MIDC), and organized by a permanent work group in accordance with the local productive demands (GTP-LPA). This group was officially established in August 2004, by way of the inter-ministerial edict no. 200, of 08/03/2004 (published once more on 10/24/2006 and on 04/24/2008), with the support of a technical secretary, located at the organizational structure of the Ministry of Development, Industry and Foreign Trade to put into practice an integrated support methodology for local productive arrangements, on the basis of the articulation of government actions (MIDC, 2010/2007).

Following this line of thought, the choice of the productive arrangements was made for pilot-studies during which some criteria were created. They are: the institutional performance of the development stages in terms of an integration with the territory and the capability of cooperation between firms and with support entities, among others. In sequence, 
the adoption of mechanisms to receive projects was made a priority, as well as the engagement of state institutions to stimulate and commit the LPA leaderships in the processes of developing local development plans and consequent institutional and entrepreneurial articulations.

In order for us to successfully play this role, state nuclei were set up, or similar organizations in the states, to carry out the demands from LPAs, as well as to analyze their proposals and to foster institutional articulations.

For that reason, a performance methodology was established to seek agreements and partnerships among the local actors (animator agent), in accordance with their demands, aiming at the organization of projects and their commitment to the possible forms of solution to the problems that arise in their acting spaces.

In the search for the sedimentation of concepts and generation of environments, from the needs of the geographical location constructed from its territorial basis, the First Brazilian Conference on Local Productive Arrangements was held in August 2004, in Brasilia, with the participation of nearly 400 people, whose discussions were organized into eight theme panels that presented the roles of the governmental and non-governmental institutions in the support of the local productive arrangements and the existing support tools and mechanisms. In each panel, successful cases were presented, in order to foster the exchange of knowledge and experiences in the development of Local Productive Arrangements.

The themes approached in that event were: Panorama and Challenges for the Construction of LPA Public Policies; Cooperation and Governance; Entrepreneurial and Worker Qualification; Internal and External Market; Commercial Intelligence; Access to Financial Services; Innovation: Collective Knowledge and Learning, and Culture and Business: Generating Products and Services with a Competitive Difference. Those themes provoked much criticism, for the debaters argued that the approaches gave priority to the economic aspect and that essential aspects of the territories and of the local reality were disregarded, as well as the educational focus of the need to invest in middle level technical qualification, to expand knowledge as a result of the emerging labor demands.

As a follow up to the debates, the Second Brazilian Conference on Local Productive Arrangements was held, with a chosen theme: "The credit and financing of micro and small businesses", which was amply discussed, in September, 2005, in Rio de Janeiro - RJ, with around 350 participants. On that occasion, eight workshops were proposed and the following themes were approached: Governance and Cooperation - Collective Investments; Financial Services for Exporting MPMEs (Micro, Small and Medium-Size Enterprises) and ; Governance and Cooperation - Qualification; Marketing in the Internal Market and Government Procurement; Innovation and Technology; Trademarks, Certification and Environment; Regional Development and Tourism, and Production Organization.

The results of those debates were an important source of information for the definition of possible courses and projects and launchings of educational programs in the area of professional and technological education, such as the Professionalized Brazil Program (PBP) and the current configuration of the Access to Technical Education and Jobs National Program (ATEJNP/PRONATEC). The former, launched in December, 2007, whose goal was to give incentive to young people and adults to return to school, coupling the raise in schooling (EJA) with technical professional development (TPD/PROEJA), to contribute for the improvement of the social and educational indicators, especially IDEB's (Brazilian Educational Development Rate), in the whole country. The latter, launched in October, 2011, had the main objective of expanding the offer of courses in Professional and Technological 
Education, bringing those offers to the hinterlands of the country and making access to the courses democratic for the Brazilian population. For that matter, a series of technical and financial assistance subprograms, projects and actions were foreseen that, together, proposed to offer eight million places for Brazilians with different profiles, in the next four years.

At the two conferences referred to, the GTP-LPA showed the results of their actions that affect productive arrangements, the updating of the LPA survey in the country, and the strategy for amplifying integrated performance with the support of the LPA States Nuclei, in addition to the Brazilian Products Showcase for sixteen Local Productive Arrangements, the former having been held in Salvador, Bahia, in 2008, and the latter in Florianópolis, Santa Catarina, in 2010. In November, 2007, the Third Brazilian Conference of Local Productive Arrangements was held in Brasilia. Nearly 750 participants attended the Conference, among entrepreneurs, sectorial leaders, scholars, LPA managers, and representatives of LPA State Nuclei and of governmental institutions.

The Conference had two panels on the theme "LPAs as a Development Strategy" and eight Sectorial Round Tables on the themes: Tourism, Agricultural Basis, Shoes, Information Technology, Biotechnology, Mineral Basis and Animal Basis. The themes approached during that event were: Internal and External Market Access, Development and Qualification, Technology and Innovation, Credit and Financing, and Governance and Cooperation.

The debates concentrated on the challenges of public policies for the development of LPAs, with an emphasis on integrated and sustainable planning of the locality and the productive sector, associating it to the valuing of the historical-cultural identities, the preservation of the environment and the increment of social capital.

The Fourth Conference was held in Brasilia, in 2009, and the event's theme was "Analysis of the National and International Experience - Local Productive Arrangements: Strategies for the Future", with around 900 participants.

At that event, ten Sectorial Round Tables were formed, during which some successful LPAs were discussed. In addition, the GTP-LPA institution actions were shown and the following structuring axes were dealt with transversally: Internal and External Market Access; Development and Qualification; Technology and Qualification; Access to Financial Services; Quality and Productivity; Governance and Cooperation.

At the Fifth and latest edition of the Conference, also held in Brasilia, in 2011, the central theme of the discussion was "Competitiveness and Sustainability". It gathered 800 people that had the opportunity of participating in the defining of the next steps for the development of the 2nd Generation of LPA Public Policies, in addition to strengthening the relations between institutions and LPAs.

We remark that, during the days of the event, theme tables were composed and the following themes were dealt with: "Productive Inclusion and Social Responsibility for LPAs"; "Innovation, Credit and Productive Microcredit, Knowledge and Technology"; "Expansion of Access to Local, Regional, National and International Markets", "Cooperation and Governance: New Perspectives and Approaches", "The Role of Professional Qualification in the Development of LPAs", "Large, Small and Medium-size Enterprises in LPAs: Does the size of the firm matter?", "Services in LPAs and LPA Services", "The Role of the Government in the Development of LPAs and the Coordination of State, Regional and National Instances".

Specifically, in this fifth edition, the "Timeline of LPA Policies for Brazil" was presented every day in multimedia panels, during the event, and it was constructed based on 
the files of initiatives and actions developed in the last 10 years by the GTP-LPA institutions and by the LPA Support State Nuclei.

Finally, we must also say that, after the Fourth and Fifth BC-LPA editions ended, post-events were held. Those LPA MERCOSUL Clusters and Associated Countries Meetings had the participation of about 100 government and academic representatives from Argentina, Bolivia, Brazil, Chile, Colombia, Paraguai, Peru, Uruguai and Venezuela. Each country's knowledge of experiences was placed on the agenda, with an emphasis on the following aspects: Productive inclusion and social responsibility; Innovation, knowledge and technology; Access to the local, regional, national and international markets; Cooperation and governance; Professional qualification; Credit and productive microcredit for LPAs; and The Role of governments in the development of LPAs.

In view of that, we can recognize the existence of a local productive arrangement starting from a set of variables that are present in different degrees of intensity, analyzing the documents developed by the GTP-LPA. It is also clear that an LPA should characterize itself for having a significant number of enterprises in the territory and of individuals that act around a predominant productive activity and for sharing forms of cooperation and some mechanism by which the local governance must be considered as a process of coordination of the actions involving the LPA agent where there are small, medium-size and large enterprises. As a consequence, the importance of the relation of professional, scientific and technological education in the construction of knowledge and teacher development is remarked to improve the quality of the technical courses, as well as the generation of innovations and local development.

As a special fact, as of 2007, the updating of the institutional survey of the local productive arrangements, carried out in the country by means of data gathering at different stages, considering the population, Human Development Rate (HDR), GNP, the number of businesses per size of the locality, the number of jobs and production volume, to build a set of social and economic standardized data on the local productive arrangements. Furthermore, the aspects of education that are used as a world reference rate for the discussion about Human Development - HDR were listed; they include three components: the percapita income represented by the GNP, the longevity and the schooling. Therefore, "the indicator used to measure longevity is the expected life years at birth, the schooling is measured by means of the illiteracy rate and the school registration rate in the three levels of education"( Feichas \& Guimarães, 2009, p. 310) and proposed in 1990 by the United Nations Development Program (PNUD).

Nowadays, the GTP-LPA meets in the scope of the Federal Government, under the coordination of the Ministry of Development, Industry and Foreign Trade (MIDC), for the continuity of the inter-institutional articulations in support of the local productive arrangements, with the objective of creating an opportunity for the complementation of the actions of entities from different localized sectors, such as individual entrepreneurs, unions, associations, qualification, education, credit, technology and development entities, among others.

Those actions by the entities need to be developed together, from the point of view of cooperative practices, which will certainly depend on the social capital characterized in the social and systemic organization of the local existing groups. This will guide the educational role in the territory, due to the important relation to be formed between the educational and social contexts established to facilitate all the coordinated action. 
What can be perceived is that the subject cooperation and governance was present in the five BC-LPAs, in the discussions of the theme groups. This refers us to the institutionalization of the local governance that should be related to a coordination of the actions performed by different LPA interlocutors.

With regard to that, the broad meaning of the term governance should be highlighted, as described by Guimarães-Iosif (2012, p. 17)

(...) it reached the field of education in the 1990's by way of World Bank documents and, since then, has been used in the wording of many official documents, agreements and national and international educational projects. From then on, several academic studies were developed, seeking to better understand this new terminology that became part of the educational glossary in the whole world.

As we resume the sense of local governance, we infer that the State participation will imply the sustainability of the social capital and of the socio-productive processes. Placed on the level of public policies, it will contribute to generate external LPA factors, with adherence to the theoretical principles of global governance permeated by rules and procedures that structure the relations throughout the world and in the process of non-hierarchically creating policies. Essentially, from a deeper view of the actors present, the State role will diminish and the management level will increase. This goes through the complexity of the spaces and of the development of policies, as explained by Shultz (2012) in three terms: closed - in which those excluded cannot enter; guests - the groups follow rules; and required - the groups ask to enter for the right to participate.

In this case, Shultz (2012, p. 34) argues: "governance, can be seen as in the standards for decision-making and in the relations that surround the political processes and the implementation programs".

Likewise, Cassiolato \& Szapiro (2003) close the idea of governance stating that it should be linked to local, democratic practices by the intervention and participation of the actors belonging to different categories, as concerns to the territorial decision processes.

\section{Professional, scientific and technological Education and local development: considerations}

In the whole world, the decisions regarding the directions of Education go through political orientations based on the State and Government objectives, such as the recent studies that suggest the construction of projects in the educational field adjusted to whole education for some of the local development ways to be reached (Ministério da Educação, 2007)

Similarly, Stromquist \& Monkman (2000) say that education has been transformed by these dynamic, powerful, committed policies under the influence of various globalization trends in which the distinction of capabilities to expand and re-dimension human capital are included.

This view refers to the logic of the Brazilian educational policies, which along the line of the current federal government, are based on the professional education value. With regard to that, Pacheco (2012, pp. 54-55) contributed important inferences, such as "in relation to the polarization between the local and the global, the tensions are provoked, on the one hand, by the organization of the capitalist economy world system, by the world's educational market growth, by the development of international curriculums, domination of the neo-colonizing culture and by the professional certification models of international value." 
From a future perspective, we suggest that the aforementioned projects be associated with the professional education trends and submitted to more complex issues like, for instance, changes in the curriculum organization and in the structural order that involve: personnel - hiring of teachers and specialists; and infrastructure - setting up of scientific and technological laboratories, building of new schools, reforms and expansions, among other things.

From that perspective, and with the growing educational connection to the local productive arrangements referred to, we also understand that the establishment of partnerships with private enterprises, and with other pertinent entities geared towards labor, they could jointly open ways for local development, given the relevance attributed to knowledge, learning, creativity and the dynamism generated by the new techno-economic scenario in the world.

We can perceive that the local productivity arrangements are directly related to educational factors, mostly to the professional education's, for contemplating some aspects like: the social, cultural, economic, environmental, territorial, institutional and political ones. In addition, they indicate a concrete form for the construction of citizenship and insertion of young people in the society, considering the exclusion and social inequality that are confirmed by their distancing from urban areas, or by their approaching peripheral zones of big cities.

Hence, in that scenario, Abdi, Shultz (2008) and Shultz (2012) note that global citizenship is positioned in ethical and normative contexts to letimize big projects and generate products originating from diversity rather than the mere utilization of the institutional tool to serve specific groups or to deal education as a "commodity", emphasizing the commercial characteristics.

In view of all that has been said, the relevance of the public policies' political articulation can be perceived on the territorial plane, with professional education and local development. Andrade \& Castioni (2010, p. 126) warn in that respect: "The challenge is to rethink secondary school, giving the student perspectives that it is not a mandatory passage for his access to a higher level professionalization, but may secondary school actually be a phase in life that will provide the young students with the means to experience work opportunities and the discovery of human values" (...)

We understand that the current projection of professional, scientific and technological education is associated with the productive context, mainly in the valuing of the knowledge of the actors involved. For that to happen, it is important that the teaching and research institutions become active agents to formalize the local productive arrangements not only in the economic scope, but with discussions to foster the universalization of education.

\section{References}

Abdi, A. A. (2012). Políticas educacionais internacionais em tempos de globalização neoliberalismo: desafios ao desenvolvimento social. In R. Guimarães-Iosif (Org.), Política e Governança Educacional: contradições e desafios na promoção da cidadania (pp. 41-63). Brasília, Distrito Federal: Liber Livro.

Abdi, A. A. \& Guo, A. S. (2008). Education and social development an Introdution: Global Issues and Analyses. Rotterdam:Sense Publishers.

Abdi, A. A. \& Shultz, L. (2008). Educating for human rights and global citizenship. New York: Sate University of New York Press. 
Andrade, M. C. C. \& Castioni, R. (2010). Educação profissional em uma perspectiva internacional comparada e suas repercussões no Brasil. Linhas Críticas, 16(30), 129-127.

Cassiolato, J. E., Lastres, H. \& Matos, M. (2008a). Arranjos Produtivos Locais: uma alternativa para o desenvolvimento criatividade e cultural. (vol. 1). Rio de Janeiro: E-Papers.

Cassiolato, J. E., Lastres, H M. \& Stallivierei, F. (2008b). Arranjos Produtivos Locais uma alternativa para o desenvolvimento: uma experiência de políticas. (vol. 2). Rio de Janeiro: E-Papers.

Cassiolato, J. E. \& Szapiro, M. (2003). Uma caracterização de arranjos produtivos locais de micro e pequenas empresas. In H.M.M. Lastres, J.E. Cassiolato \& M.L. Maciel (Orgs.), Pequena Empresa: Cooperação e Desenvolvimento Local (pp. 35-50). Rio de Janeiro: Dumará.

Ciavatta M., Frigotto, G. \& Ramos, M. (Orgs.). (2005). Ensino Médio Integrado: concepções e contradições. São Paulo: Cortez.

Coriolano, L. N. M. T. (Org.). (2009). Arranjos produtivos Locais do turismo comunitário: atores e cenário em mudanças. Fortaleza: EdUECe.

Costa, E. J. M. (2010). Arranjos Produtivos Locais, Políticas Públicas e Desenvolvimento Regional. Brasília, Distrito Federal: Mais Gráfica Editora.

Feichas, S. A. Q. \& Guimarães, R. P. (2009). Desafios na Construção de Indicadores de Sustentabilidade. Ambiente \& Sociedade, 12(2), 307-323.

Gramsci, A. (1989). Os intelectuais e a organização da cultura. Rio de Janeiro, Civilização Brasileira.

Guimarães-Iosif, R. (Org.). (2012). Política e Governança Educacional: contradições e desafios na promoção da cidadania. Brasília, Distrito Federal: Líber Livro.

Ministério da Educação. (2007). Educação Profissional em sintonia com a realidade social. Brasília, Distrito Federal: Salto para o Futuro.

Ministério da Educação. (2012). PRONATEC-Programa Brasil Profissionalizado em 2102. Retrieved October 15, 2012, from

http://portal.mec.gov.br/ pronatec.mec.gov.br/institucional/objetivos-e-iniciativas. Ministério do Desenvolvimento, Indústria e Comércio Exterior. (2007). Manual de apoio aos arranjos produtivos locais. Brasília, Distrito Federal: MIDC.

Ministério do Desenvolvimento, Indústria e Comércio Exterior. (2010). Institucional: Grupo de Trabalho Permanente para Arranjos Produtivos Locais (APLs ) em 2012. Retrieved September, 23, 2012. from. http://www.desenvolvimento.gov.br/sitio/desenvolvimentodaproducão.

Olssen. M., Codd, J. \& O`Neill, A. (2004). Education Policy: Globalization. Citizensship and Democracy. London:SAGE, Publications LTD.

Pacheco, E. (2012). (Org.). Perspectivas da Educação Profissional Técnica de Nível Médio: Proposta de Diretrizes Curriculares Nacionais. São Paulo: Editora Moderna.

Santos, M. A. (1999). Natureza do espaço: tempo, razão e emoção. São Paulo: Hucitec.

Santos, M. \& Silveira, M. L. (2002). O Brasil: território e sociedade no início do século XXI (4a ed.). Rio de Janeiro: Record.

Saviani, D. (1989). Sobre a concepção de politecnia. Rio de Janeiro: Politécnico da Saúde Joaquim Venâncio: Fiocruz.

Shultz, L. (2012). Governança global, neocolonialismo e respostas democráticas para políticas educacionais. In R. Guimarães-Iosif (Org.), Política e Governança Educacional: contradições e desafios na promoção da cidadania. (pp. 27-40). Brasília, Distrito Federal: Líber Livro. 
Sousa Santos, B. (2006). A gramática do tempo: para uma nova cultura política. São Paulo: Editora Cortez.

Stromquist, N. \& Monkman, K. (Eds.). (2000). Globalization and education: Integration and contestation across cultures. Lanham, MD: Rowman and Littlefield.

Universidade Federal do Rio de Janeiro. (2010). Rede de Pesquisa em Sistemas de Arranjos Produtivos Inovativos Locais (Redesist). Retrieved September 13, 2012, from http://www.portalredsist.ie.ufrj.br. 